\title{
Anchored between heaven and earth - a new flightless brown lacewing from Peru (Neuroptera, Hemerobiidae)
}

\author{
Ulrike Aspöck ${ }^{1,2}$, Horst Aspöck ${ }^{3}$, Axel Gruppe ${ }^{4}$ \\ 1 Natural History Museum, 2nd Zoological Department, Burgring 7, A-1010 Vienna, Austria \\ 2 Department of Evolutionary Biology, University of Vienna, Althanstraße 14, A-1090 Vienna, Austria \\ 3 Institute of Specific Prophylaxis and Tropical Medicine, Medical University Vienna (MUW), Kinderspitalgasse 15, A-1090 Vienna, Austria \\ 4 Chair of Zoology - Entomological Division, Technical University of Munich, Hans-Carl-von-Carlowitz-Platz 2, D-85354 Freising, Germany \\ http://zoobank.org/28F525EF-C030-4E04-9706-74C64A59225F
}

Corresponding author: Axel Gruppe (gruppe@wzw.tum.de)

Academic editor: Susanne Randolf • Received 30 June 2020 • Accepted 27 July 2020 • Published 14 August 2020

\begin{abstract}
Male and female of Nusalala peruana sp. nov., a flightless hemerobiid from the Andes mountain range of northern Peru, at a height of almost $4000 \mathrm{~m}$, are described, figured and documented as the first record of a brachypterous, flightless species of Nusalala Navás, 1913, from this country. The other two congeneric, brachypterous species are from high altitudes in Colombia and Costa Rica and have been described in the male sex only - the females remain unknown. The coriaceous domed forewings are shared by all three brachypterous Nusalala species. The ribbon-like hindwings of the male of $N$. peruana sp. nov. are unique, since those of the other brachypterous males are scale-like, as are the hindwings of the female of $N$. peruana sp. nov. Distribution and evolutionary backgrounds of brachyptery and flightlessness in Neuropterida are discussed.
\end{abstract}

\section{Key Words}

Nusalala peruana sp. nov., coriaceous wings, brachyptery, flightlessness, high altitude

Camouflaged as a beetle? Not at all! It is a strategy high up in the mountains against being blown away by the wind. Flightlessness as a virtual anchor in both sexes.

\section{Introduction}

Wing reduction and flightlessness are rare phenomena in Neuropterida and have diverse backgrounds. In the order Raphidioptera, females of two inocelliid species - Inocellia fulvostigmata H. Aspöck \& U. Aspöck, 1968, and Indianoinocellia mayana U. Aspöck, H. Aspöck \& Rausch, 1992 (H. Aspöck et al. 1991; U. Aspöck et al. 1992) - are conspicuous by having disproportionally small wings and they are probably unable to fly. In the order Megaloptera, a micropterous female of a corydalid species, identified as "?Platychauliodes sp.", has been discussed as a "micropterous form or aberration" in Barnard (1940).
In the order Neuroptera, the rare examples of reduced wings and/or flightlessness are found scattered amongst the various families and most have been listed by Oswald (1996) [1997]. We know from our studies on Trichoma gracilipenne Tillyard, 1916, Berothidae (U. Aspöck and H. Aspöck 1985), Dilar parthenopaeus Costa, 1855, Dilaridae (H. Aspöck et al. 1980; Pantaleoni and Letardi 1996), Helicoconis aptera Messner, 1965 (Rausch et al. 1978), Helicoconis hirtinervis Tjeder, 1960, Conwentzia psociformis (Curtis, 1834) and C. pineticola Enderlein, 1905, Coniopterygidae (H. Aspöck et al. 1980), that these wing reductions and differentiations or evolutionary "escapades" originated from completely different preconditions and, as far as 
is known, reduced wings and flightlessness concerns mainly, but not entirely, the females.

Recently, a new species of the genus Adamsiana (Ithonidae), described from Guatemala (Ardila-Camacho et al. 2020), represents the second species of the genus that is characterised by completely wingless females. In Hemerobiidae, Psectra diptera (Burmeister, 1839 ) is polymorphic with respect to the hindwings (brachypterous specimens are probably flightless), but no convincing hypotheses have been put forward explaining the "whys" and "wheres" of this phenomenon (H. Aspöck et al. 1980).

The family Hemerobiidae comprises 11 brachypterous species (Oswald and Machado 2018). The struggle for survival, whether in harsh coastal lowlands of islands or high on inhospitable mountains, is regarded as the main evolutionary catalyst. Studies concerning these phenomena are summarised in Oswald (1993, 1996 [1997]) and C. Tauber et al. (2007). In addition, Handschin (1955), Zimmermann (1957) and Penny and Sturm (1984) deserve individual mentioning, as each goes far beyond a routine description of (new) brachypterous species.

In the present paper, a new species of the genus Nusalala Navás, 1913, is described. It is the third brachypterous species discovered in the genus and, quite remarkably, it was found in both sexes. The other two brachypterous species, N. andina Penny \& Sturm, 1984, from Colombia and N. brachyptera Oswald, 1997, from Costa Rica, are known from the males only. One Nusalala female is placed provisionally in N. brachyptera, but it is not designated as paratype and remains, in fact, undescribed (Oswald 1996 [1997]).

The flightlessness of Nusalala peruana sp. nov. is discussed in the context of its ecological niche and systematic position.

\section{Materials and methods}

All specimens were collected in yellow pan traps, which were laid out on the grass. The pans contained water with hair shampoo and were checked after 24 hours. After cleaning the insects in water, they were transferred to a container with 70-96\% ethanol. After transport to the lab, the specimens were removed from alcohol and mounted with glue on stripes of stiff paper.

Genitalic preparations were made by clearing the apex of the abdomen in cold potassium hydroxide (KOH) (approx. $10 \%$ in water) for five hours. After rinsing off the $\mathrm{KOH}$ with distilled water, the apex of the abdomen was transferred to glycerine for further examination.

Photographs were taken with a Leica DFC camera attached to a Leica MZ16 binocular microscope and processed with the help of Leica Application Suite. They were then stacked with Zerene Stacker 64-bit and processed with Adobe Photoshop Elements 8.

Terminology of the genitalia follows U. Aspöck and H. Aspöck (2008).

\section{Taxonomy}

Genus Nusalala Navás, 1913

\section{Nusalala peruana sp. nov.}

http://zoobank.org/B551F33F-D24B-4F27-AC28-0BECD2CC11C5 Figs 1-16

Diagnosis. The new species can be differentiated from most other species of Nusalala Navás, 1913, by the following combination of characters: Forewings coriaceous and domed, covering legs and body (Figs 1, 2, 4-6); hindwings long and ribbon-like in the male (Fig. 7), micropterous and scale-like in the female (Figs 12, 13). Venation in both wings reduced and partly vestigial in both sexes. The coriaceous forewings differentiate $N$. peruana sp. nov. from all other Nusalala species, except $N$. andina Penny \& Sturm, 1984, and N. brachyptera Oswald, 1997. The males of the latter two species have scale-like (not ribbon-like) hindwings. The female of $N$. andina is unknown. Oswald (1996) [1997] mentioned a female Nusalala which he tentatively identified as N. brachyptera due to similar wing modifications.

Description of male holotype and male paratypes (Figs 1-11). Head blackish-brown; frons, labrum and genae polished, without pilosity; occiput covered with golden brownish setae. Antennae with broad cylindrical scapus, slim cylindrical pedicellus, 40-45 moniliform flagellomeres, apically darker. Compound eyes dark, relatively small.

Thorax: Pronotum shield-like, blackish-brown, with dense brownish pilosity. Legs brownish, only tarsalia yellowish. Each leg with two simple apical claws.

Forewings with significant concavo-convexity, heavily domed, length of domed wings $3.6 \mathrm{~mm}$, length of spread (flattened) wing $3.8 \mathrm{~mm}$, width $1.9 \mathrm{~mm}$, coriaceous, suboval, apically slightly tapered; densely covered with short hairs; colouration spotted brownish with white markings and a brownish stripe in the middle of the wing, which is proximally accompanied by a whitish stripe; colouration, however, extremely variable. Venation variable and irregularly reduced in some specimens. Costal space proximally broad, veins irregularly connected with small interjacent veins, no pterostigma discernible; subcostal space with a few irregular cross veins; radius with 3-5 radial branches; gradate series of radial space not clearly discernible; bases of radius and media fused; venation of median, cubital and anal spaces not clearly ascertainable. Hindwings ribbon-like, length $2.7 \mathrm{~mm}$, width $0.4 \mathrm{~mm}$, with a short, oblique subcosta (?) basally. Longitudinal veins branched, cross veins absent.

Male genitalia (Figs 8-11): Tergite 9 divided into a pair of hemitergites, ventrolaterally connected with ectoproct and strongly sclerotised with a broad cephalic apodeme; ectoprocts basally strongly sclerotised, with blunt terminal process. Rosette of trichobothria reduced to a single trichobothrium. Gonocoxites 9 forming broad discs, dorsally fused by a small sclerotised bridge, lateral- 

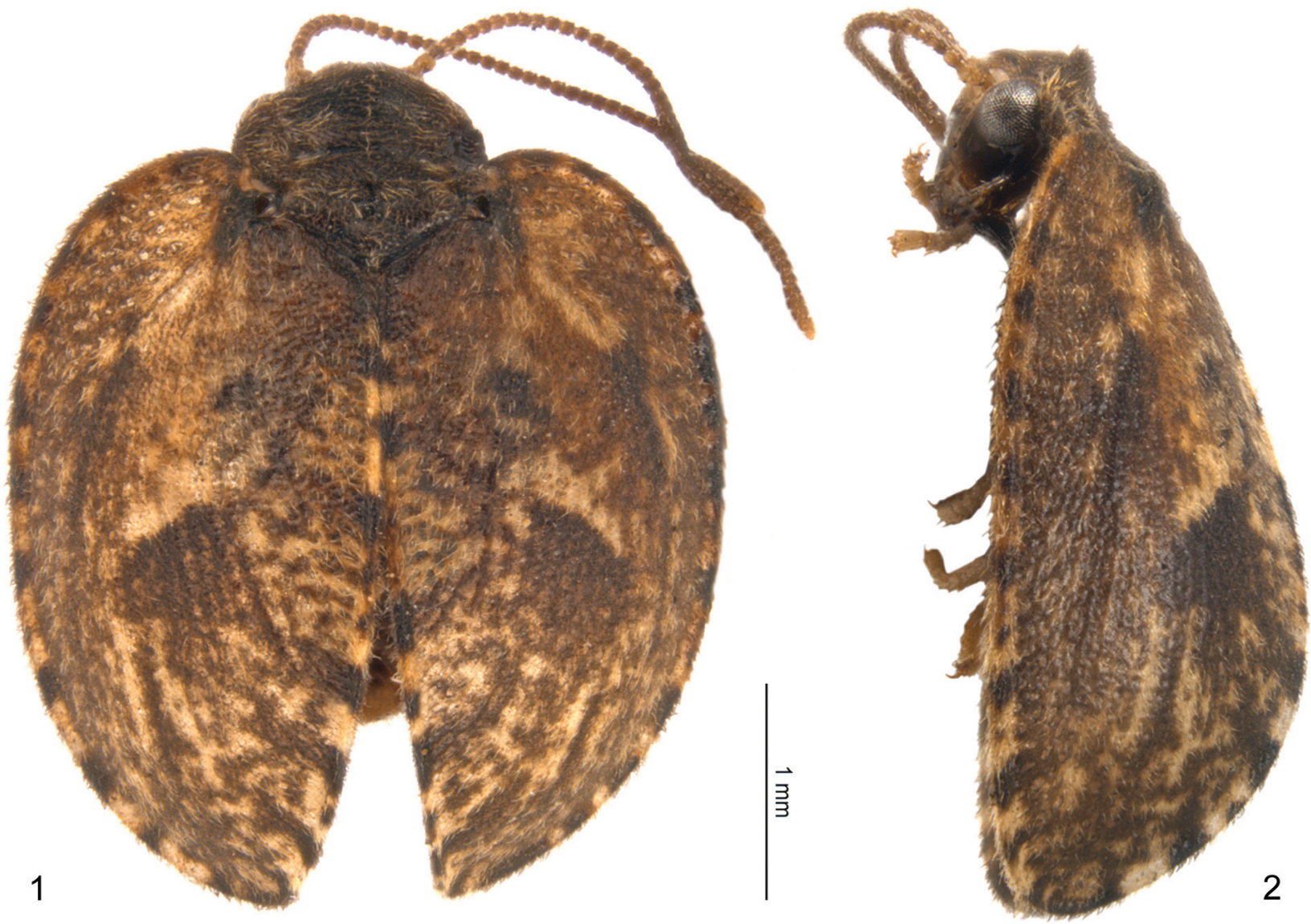

3

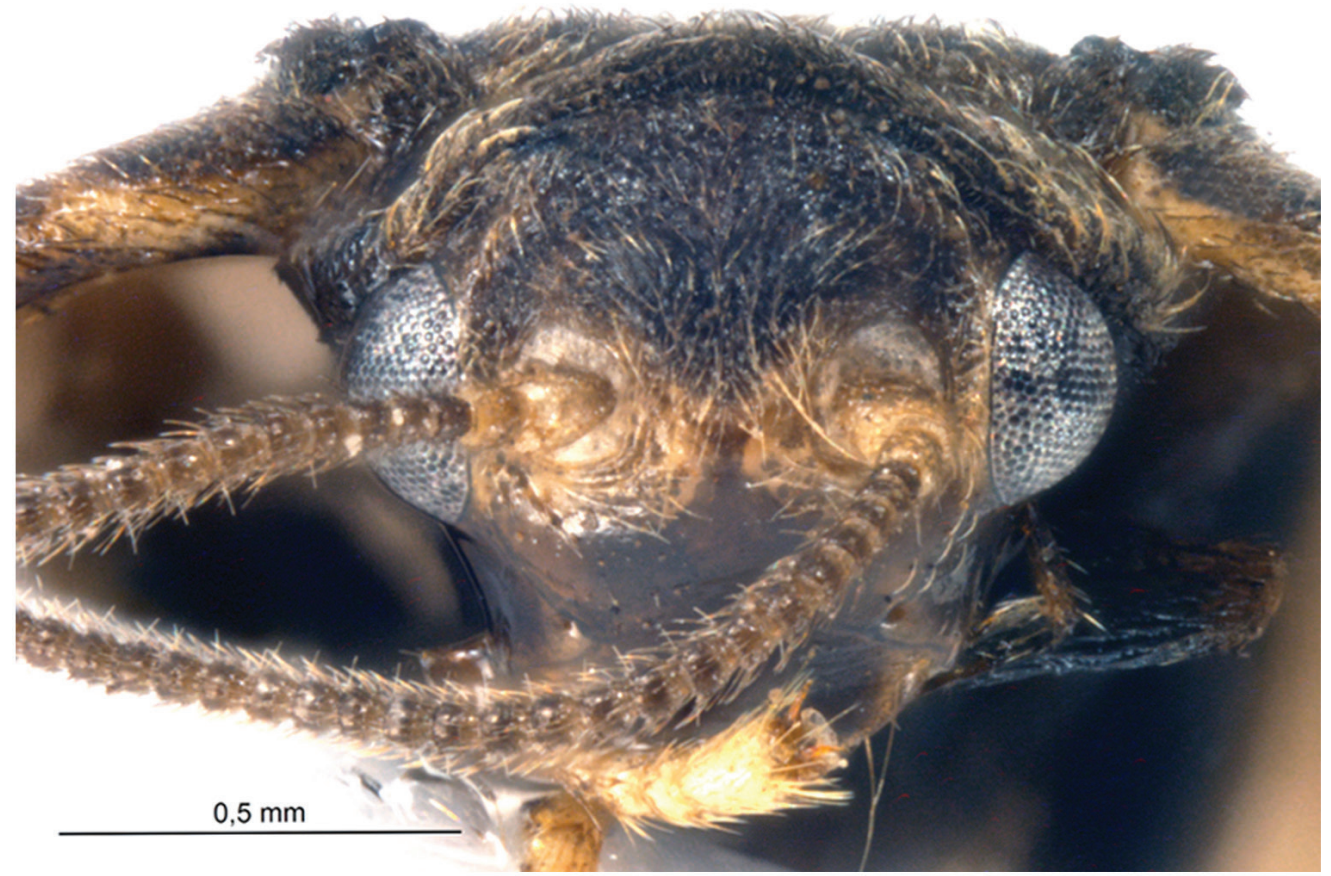

Figures 1-3. Nusalala peruana sp. nov., holotype, male. 1. habitus, dorsal; 2. habitus, lateral; 3. head frontal.

ly with two processus, the upper one representing the gonapophyses 9; the fused gonostyli 9 impressively shaped into a long, ventrally directed hook; gonocoxites 10 basally fused to an unpaired sclerite, terminally bilobed, connected with paired and slightly domed sclerites which are addressed as modified gonapophyses 10; hypandrium internum large and ordinarily shaped.

Description of the female paratype (Figs 12-16). Length of the domed forewing approximately $3.2 \mathrm{~mm}$, width $1.9 \mathrm{~mm}$. Habitus similar to male, but specimen in 

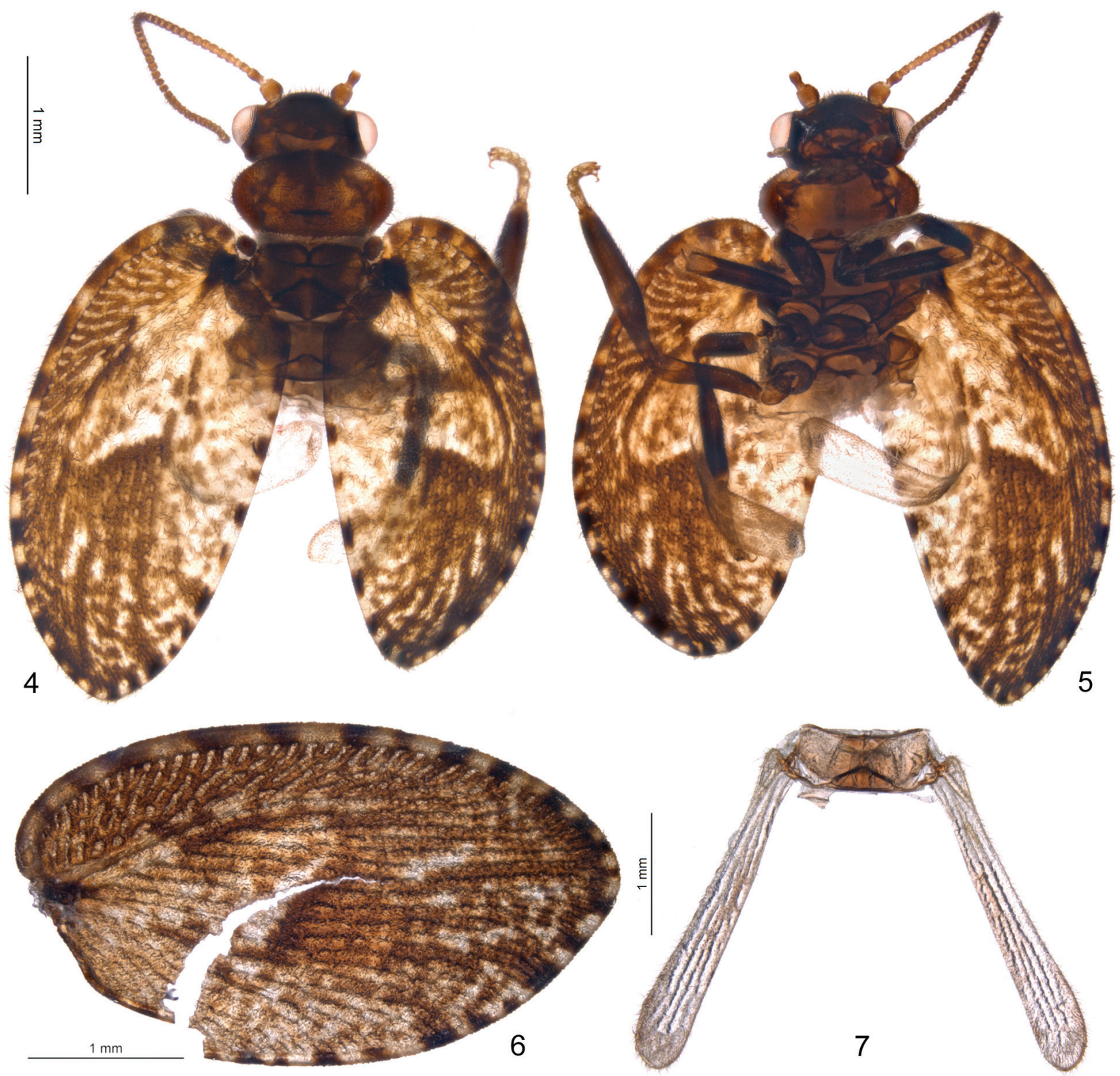

Figures 4-7. Nusalala peruana sp. nov., paratype, male (from Hualgayoc). 4. habitus, dorsal; 5. habitus, ventral; 6. right forewing (broken by spreading under cover glass); 7. metathorax with hindwings (spread under cover glass).

poor condition, only right forewing preserved, left forewing missing. Hindwing scale-like (Fig. 13).

Female genitalia (Figs 15, 16): Sternite 7 inconspicuous; tergite 8 reaching beyond spiraculum; gonocoxites 8 fused to a small strongly sclerotised sclerite (subgenitale); paired small ovoid internal sclerites are interpreted as the highly-reduced gonapophyses 8; tergite 9 small, dorsally divided, ventrolaterally broadened; gonocoxites 9 ovoid, connected with tiny (reduced) sclerites which are interpreted as gonapophyses 9; ectoproct dorsally divided, with a single trichobothrium.

Glandular systems, as described and figured in Monserrat (2000), could not be found in the single available female specimen.

Material studied. 13 males: Holotype and paratypes.
Holotype and 1 male paratype: "PERU. CA. Hualgayoc, 646'14.74"S, 78³7'30.45"W, $3851 \mathrm{~m}$ alt., 7-14. iX.2017, L. Figueroa leg.";

1 male paratype: "PERU. CA. Hualgayoc, 645'31.05"S, 78³7'19.85"W, $3997 \mathrm{~m}$ alt., 7-14. iX.2017, L. Figueroa leg."; 1 male paratype: "PERU. CA. Hualgayoc, 645'58.78"S, 78³7'33.88"W, 3968 m alt., 19.-26.Vii.2018, L. Figueroa leg."; 1 male paratype: "PERU. CA. Hualgayoc, 645'22.93"S, 78³7'28.45"W, 3875 m alt., 19.-26.Vii.2018, L. Figueroa leg."; 4 males paratypes: "PERU. CA. Hualgayoc, 6 ${ }^{\circ} 45^{\prime} 50.05^{\prime S}$, 78³9'6.20"W, $3790 \mathrm{~m}$ alt., 22.-27.Vii.2019, P. Sánchez leg."; 1 male paratype: "PERU. CA. Hualgayoc, $6^{\circ} 45^{\prime} 50.05^{\prime \prime S}, 78^{\circ} 39^{\prime} 6.20^{\prime \prime} \mathrm{W}, 3790 \mathrm{~m}$ alt., 15.-20.iii.2019, P. Sánchez leg."; 1 male paratype: "PERU. CA. Hual- 

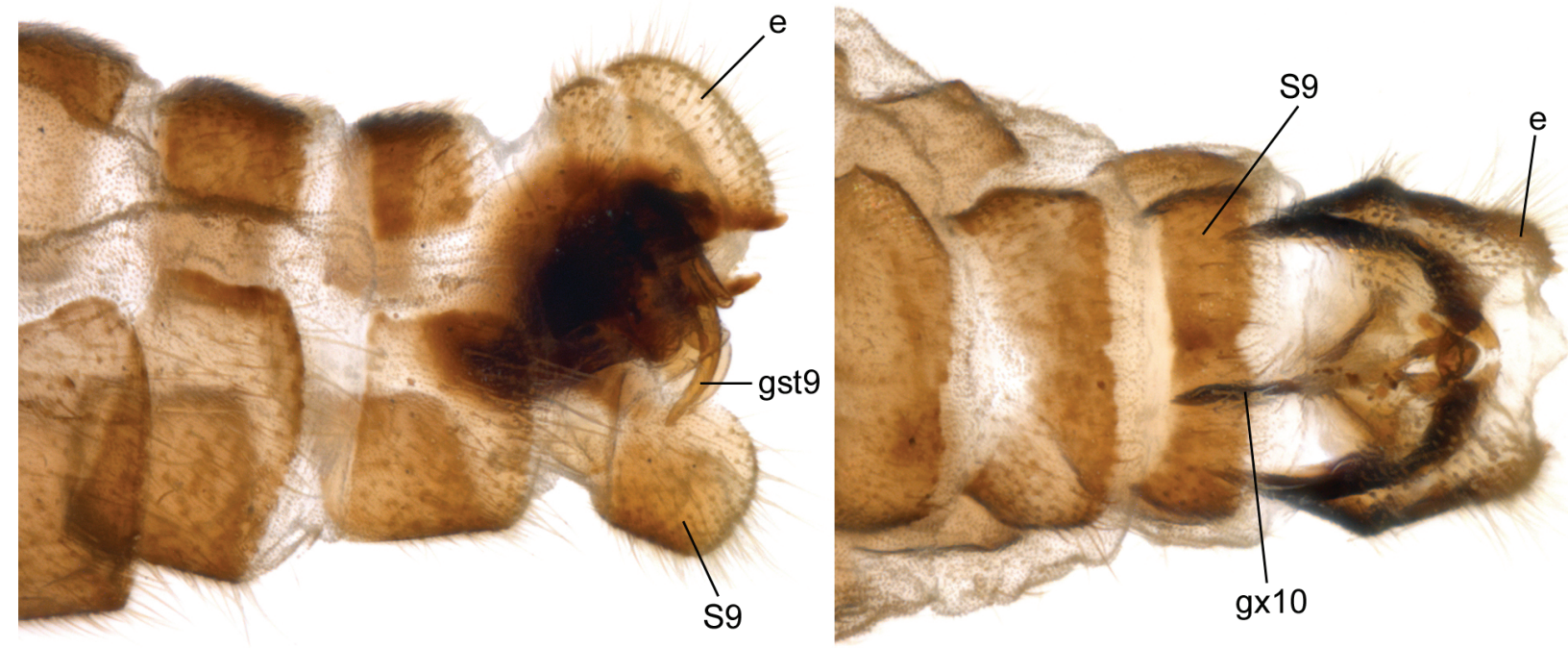

8

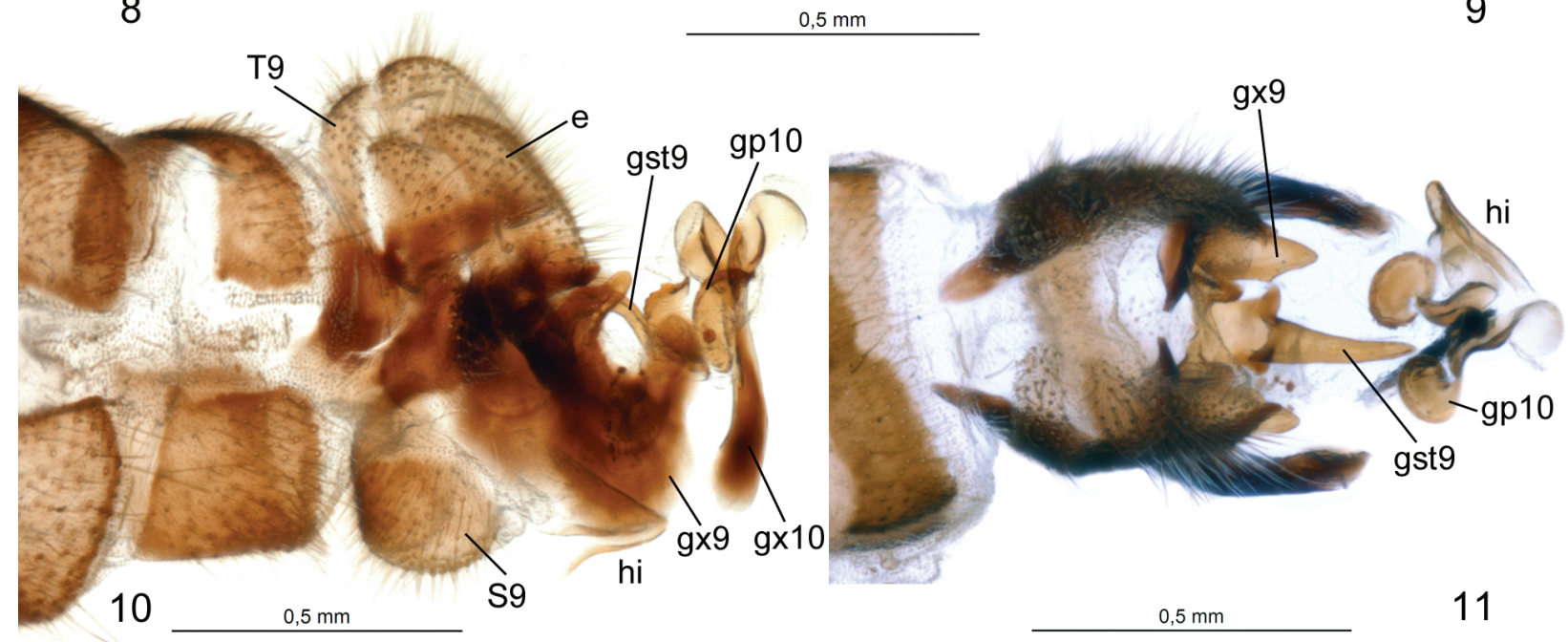

Figures 8-11. Nusalala peruana sp. nov., paratype, male (from Hualgayoc). 8. genital sclerites, lateral; 9. genital sclerites, ventral; 10. genital sclerites, lateral, partly dissected; 11. genital sclerites, dorsal, partly dissected; e - ectoproct; gp10 - gonapophysis 10 ; gst9 - fused gonostyli 9; gx9 - gonocoxite 9; gx10 - partly fused gonapophyses 10; hi - hypandrium internum; $\mathbf{S}$ - sternite; $\mathbf{T}$ - tergite.

gayoc, $6^{\circ} 45^{\prime} 42.15^{\prime \prime} \mathrm{S}, 78^{\circ} 38^{\prime}$ 54.39"W, $3756 \mathrm{~m}$ alt., 15.20.iii.2019, P. Sánchez leg."; 1 male paratype: "PERU. CA. Hualgayoc, 645'22.93"S, 78³7'28.45"W, $3875 \mathrm{~m}$ alt., 22.-27.Vii.2019, P. Sánchez leg.”; 1 male paratype: "PERU. CA. Hualgayoc, 646'55.48"S, 78³7'45.29"W, 3805 m alt., 22.-27.Vii.2019, P. Sánchez leg."

1 female paratype: "PERU. CA. Hualgayoc, $6^{\circ} 45^{\prime} 50.05^{\prime \prime S}, 78^{\circ} 39^{\prime} 6.20^{\prime \prime W}, 3790$ m alt., 7.-14.iX.2017, L. Figueroa leg."

Holotype male, 7 paratypes (6 males, 1 female) will be deposited in coll. Museo de Historia Natural Lima, 3 male paratypes in coll. Bavarian State Collection of Zoology, Munich and 3 male paratypes in coll. Natural History Museum, Vienna.

Distribution. Currently known only from the type locality in the province of Hualgayoc, Cajamarca region, Peru.

Ecology. The specimens were collected in a Puna grassland (Figs 17-19). Altitudes of findings range from
$3756 \mathrm{~m}$ to $3997 \mathrm{~m}$, time of collecting from March to September in the years 2017 to 2019 . The specimens were collected around the mine Cerro Corona within an area of $3 \mathrm{~km} \times 3.5 \mathrm{~km}$; the collecting protocol included pitfall and yellow pan traps; however, the specimens were found solely in the yellow pan traps.

Etymology. peruana = Peruvian, adjective, feminine. The epithet is an adjective apposition to the genus Nusalala (feminine).

\section{Discussion}

\section{Ecological relevance of flightlessness}

Global distribution and habitat preferences of brachypterous and, thus, flightless hemerobiids are reported in detail in Oswald (1996) [1997]. Ancestral arboreality and 

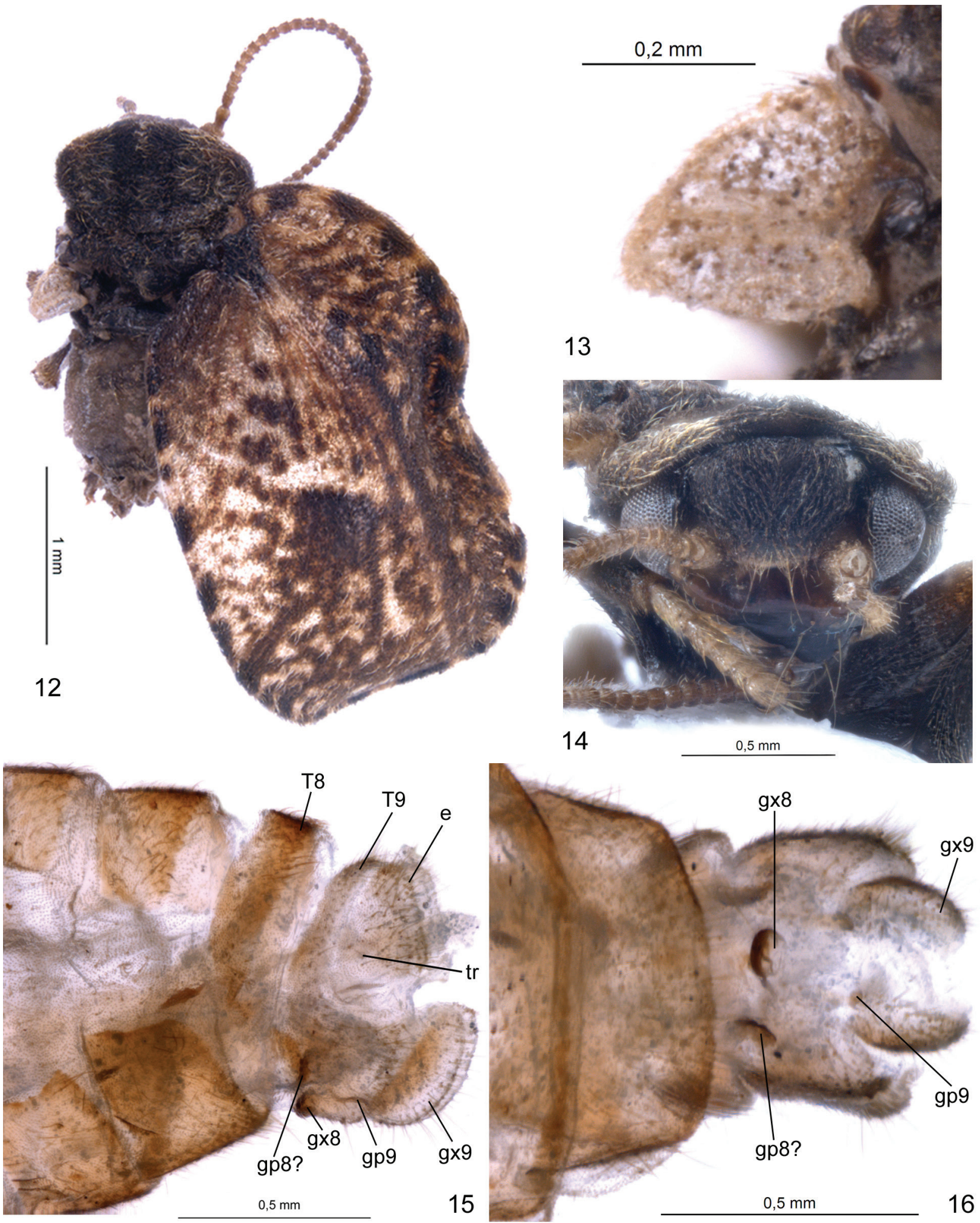

Figures 12-16. Nusalala peruana sp. nov., paratype, female (from Hualgayoc). 12. habitus, dorsal with right forewing (left forewing missing) and left scale-like hindwing; 13. scale-like left hindwing; 14. head, frontal; 15. genital sclerites, lateral; 16. genital sclerites, ventral; e - ectoproct; gp8 - gonapophysis 8; gp9 - gonapophysis 9; gx8 - fused gonocoxites 8; gx9 - gonocoxite 9; T - tergite; $\mathbf{t r}$ - trichobothrium.

multiple independent shifts to terricolousness either in the context of coastal scenarios on remote islands or at high altitudes on mountains were likewise discussed in
Oswald (1996) [1997]. However, this does not imply that the induction of these characters is understood in a genetic context (C. Tauber et al. 2007). Nusalala Navás, 

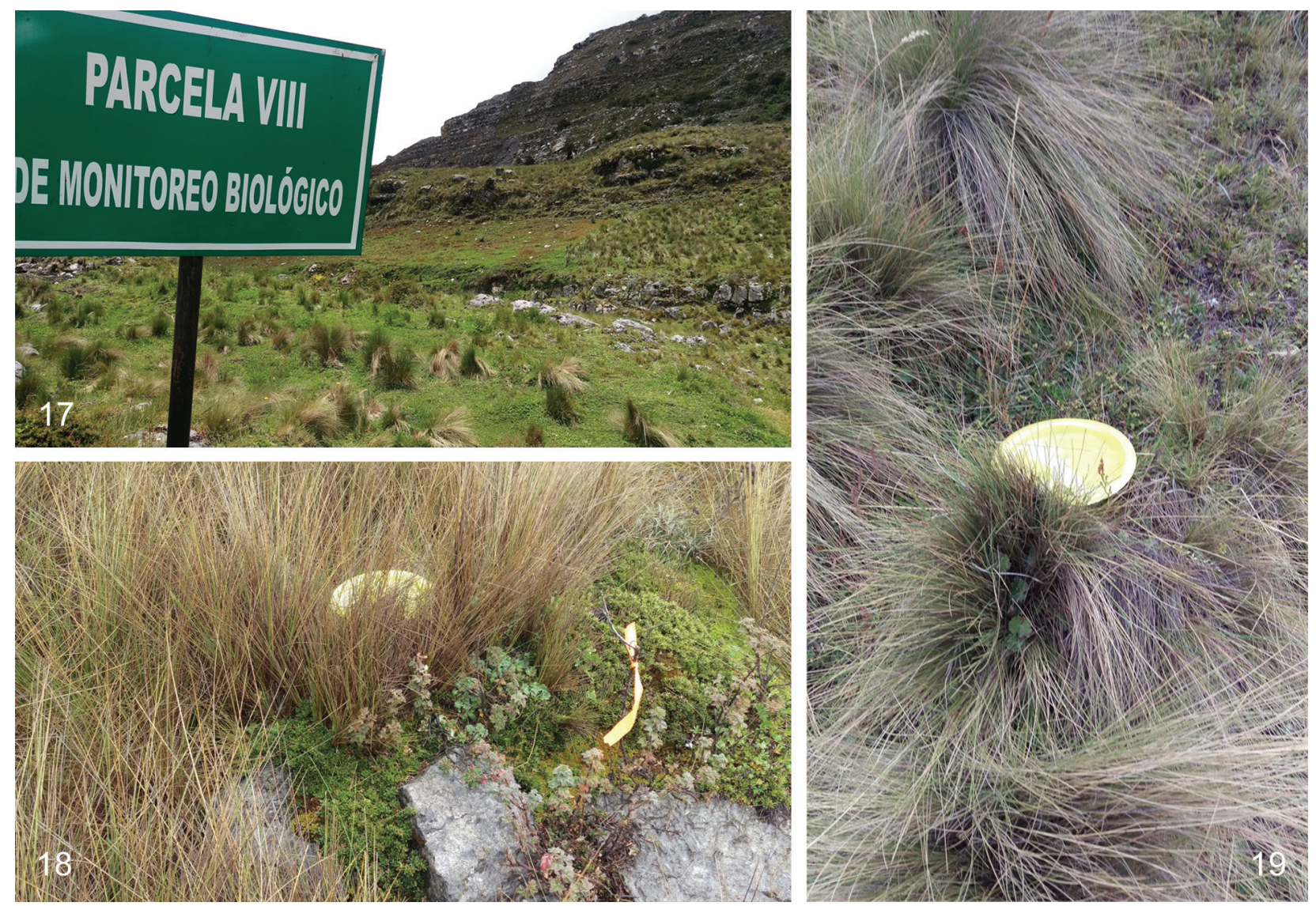

Figures 17-19. Type locality of Nusalala peruana sp. nov. 17 - landscape; 18, 19 - microhabitat with yellow pans in which Nusalala peruana sp. nov. was trapped.

1913, is a Neotropical genus known from southern Mexico, Central America, the Caribbean Islands (where it is especially rich in species) and South America with about 20 described species (Oswald 2020). It replaces the genus Micromus Rambur, 1842, in South America (Monserrat 2000; Lara and Perioto 2016).

\section{Morphological relevance of flightlessness}

Morphological relevance of flightlessness comprises the development of wing modifications, which lead not only to flightlessness, but which also provide protection against drifting by the wind.

Within Neuroptera, completely wingless females are only known from Helicoconis aptera Messner, 1965, Coniopterygidae and both known species of the genus Adamsiana, A. curoei Penny, 1996, and A. alux Ardila-Camacho, Castillo-Argaez \& Martinez, 2020, Ithonidae (Ardila-Camacho et al. 2020).

Wing modification in flightless Hemerobiidae, the phenomena of forewing reduction, forewing membrane thickening, forewing concavo-convexity and the diverse patterns of hindwing reductions are meticulously treated in Oswald's 1996 [1997] paper. It would be redundant to repeat these items here. The forewing pattern of Nusala- la peruana sp. nov. fits into the frame of the two other brachypterous Nusalala species. However, the ribbon-like shape of the hindwing of the male of Nusalala peruana sp. nov. is unique. The scale-like hindwing of the female lies within the pattern of scale-like shapes of wing reductions.

Irrespective of these theoretical considerations, it is unknown how the brachypterous specimens could have fallen into the yellow pan traps, possibly they crawled up the grass and fell into the pans (attracted by shampoo?).

\section{Phylogenetic relevance of flightlessness}

Oswald (1996) [1997] depicted the phylogenetic distribution of flightlessness in the family Hemerobiidae on the basis of his previous cladograms (Oswald 1993) and demonstrated that this phenomenon has a scattered occurrence in Notiobiellinae (Psectra Hagen, 1866), Drepanacrinae (Conchopterella Handschin, 1955) and Microminae (Nusalala Navás, 1913, Micromus Rambur, 1842). According to the most recent phylogenetics of the Hemerobiidae (Garzón-Orduña et al. 2016) and following the tree therein, the genera Nusalala and Micromus are still within Microminae, but Psectra is integrated in the newly-erected subfamily Zachobiellinae, while Conchopterella remains in the Drepanacrinae. Parallel and 
independent evolution of flightlessness is corroborated, thus leading again to the hypothesis of similar underlying selective pressures.

Nonetheless and quasi as advocatus diaboli, we may reflect upon a common ancestry of the three brachypterous Nusalala species, namely $N$. brachyptera in Costa Rica, living in the ground litter at heights of 2750-3350 m, $N$. andina, from Colombia, living in tufts of Calamagrostis effusa at $3800 \mathrm{~m}$ and $N$. peruana sp. nov., living in a Peruvian Puna grassland at heights of 3756-3997 m. Do these three brachypterous Nusalala species have a common stem species? Are they a monophylum or has each of them its particular, but inconspicuous, "normal" sister species?

Based on the morphology of male genital sclerites, Monserrat (2000) considered the brachypterous N. andina from Colombia as being closely related to $\mathrm{N}$. colombiensis (Banks, 1910) from Colombia and Peru and $N$. brachyptera from Costa Rica as being closely related to $N$. championi Kimmins, 1936, from Guatemala, Panama, Costa Rica and Mexico.

The question, which of the many Nusalala species with normal wings known from Central and South America (Monserrat 2000, 2004; Lara and Perioto 2016; Martins 2019; Oswald 2020) might have a common stem species with $N$. peruana sp. nov., cannot be answered yet.

Finally, given that flightlessness in Hemerobiidae evolved several times parallel and independently, it is extremely unlikely that each of the concerned species started from scratch (with sufficient numbers of mutations in a sufficient number of specimens in the course of sufficient shifts by the wind to high mountains, the fittest then having been selected). In fact, quite another scenario comes into consideration: the reactivation of ancient available patterns from common ancestors. May these be the "elytra" of the common stem species of Coleoptera and Neuropterida or does it lead back to Hemimetabola - like Orthoptera ("tegmina"), Hemiptera ("hemelytra") or Dermaptera?

On the one hand, there are genes that control the character identity of the two pairs of wings associated with the second and third segment of the thorax of pterygote insects. On the other hand, there are genes determining the various character states, as they are responsible for the special shapes of the wings. Experimental evidence of the complexity of the network behind these genes and deeper insights gained from the "Drosophila melanogaster scenario" have been discussed by Wagner (2007) in the context of the developmental genetics of homology. Although the genetic backgrounds of the evolution of brachyptery and flightlessness in Neuroptera still remain a conundrum, we are convinced that they are controlled by the above mentioned networks.

\section{Acknowledgements}

The material was collected in the project "Monitoreo de Biodiversidad en el área de influencia de la Unidad Minera Cerro Corona" with the permission of "El Servicio Nacio- nal Forestal y de Fauna Silvestre" (SERFOR). The permit number was RDG Nro. 234-2017-SEROR-DGGSPFFS.

Cordial thanks to both collectors of $N$. peruana, Luis Figueroa and Pavel Sánchez, special thanks to Luis Figueroa for providing photographs of the type locality. We are grateful to Dr Diana Silva Dávila and Dr Mabel Alvarado Gutiérrez, Museo de Historia Natural Lima, Peru for arranging the loan. We also want to thank Dr Juliane Diller for introducing us to the museum in Lima. Many thanks to Mag Harald Bruckner, Natural History Museum Vienna, for providing photographs of the type material and to Dr John Plant for polishing the English and critically reading the manuscript.

Sincere thanks to Dušan Devetak (Maribor), Peter Duelli (Zürich), Caleb Califre Martins (presently Mexico City), Alexi Popov (Sofia) and Susanne Randolf, Subject Editor (Vienna) for thoroughly reviewing and improving the manuscript. We gratefully acknowledge the Museum für Naturkunde Berlin for waiving the author's fees.

\section{References}

Ardila-Camacho A, Castillo-Argaez R, Martínez JI (2020) A new species of Moth Lacewing from the Mesoamerican Genus Adamsiana Penny 1996 (Neuroptera: Ithonidae). Neotropical Entomology. Pre print, 10 pp. https://doi.org/10.1007/s13744-020-00773-y

Aspöck H, Aspöck U, Hölzel H (unter Mitarbeit von Rausch H) (1980) Die Neuropteren Europas. Eine zusammenfassende Darstellung der Systematik, Ökologie und Chorologie der Neuropteroidea (Megaloptera, Raphidioptera, Planipennia) Europas. Mit 96 Bestimmungsschlüsseln, 12 Tabellen, 913 Strichzeichnungen, 259 Fotografien, 26 Aquarellen und 222 Verbreitungskarten. Goecke und Evers, Krefeld: 2 Bde: 495 pp.; 355 pp.

Aspöck H, Aspöck U, Rausch H (1991) Die Raphidiopteren der Erde. Eine monographische Darstellung der Systematik, Taxonomie, Biologie, Ökologie und Chorologie der rezenten Raphidiopteren der Erde, mit einer zusammenfassenden Übersicht der fossilen Raphidiopteren (Insecta: Neuropteroidea). Mit 36 Bestimmungsschlüsseln, 15 Tabellen, ca. 3100 Abbildungen und ca. 200 Verbreitungskarten. Goecke \& Evers, Krefeld: 2 Bde: 730 pp; 550 pp.

Aspöck U, Aspöck H (1968) Zwei neue Inocelliiden-Spezies aus Asien (Neuroptera, Raphidiodea). Entomologische Berichten, Amsterdam 28: 184-189.

Aspöck U, Aspöck H (1985) Die Berothiden Australiens (und Neuseelands) II: Die Genera Trichoma TILLYARD, Trichoberotha HANDSCHIN, Protobiella TILLYARD und Austroberothella n. g. (Neuropteroidea: Planipennia: Berothidae). Zeitschrift der Arbeitsgemeinschaft Österreichischer Entomologen 36(3/4): 65-85.

Aspöck U, Aspöck H (2008) Phylogenetic relevance of the genital sclerites of Neuropterida (Insecta: Holometabola). Systematic Entomology 33: 97-127. https://doi.org/10.1111/j.1365-3113.2007.00396.x

Aspöck U, Aspöck H, Rausch H (1992) Rezente Südgrenzen der Ordnung Raphidioptera in Amerika (Insecta: Neuropteroidea). Entomologia Generalis 17(3): 169-184. https://doi.org/10.1127/ entom.gen/17/1992/169

Banks N (1910) New South American neuropteroid insects. Proceedings of the Entomological Society of Washington 12: 146-160. 
Barnard KH (1940) Additional Records, and Descriptions of New Species, of South African Alder-flies (Megaloptera), May-flies (Ephemeroptera), Caddis-flies (Trichoptera), Stone-flies (Perlaria), and Dragonflies (Odonata). Annals of the South African Museum 32: 609-661.

Burmeister HCC (1839) Handbuch der Entomologie. Zweiter Band [=Vol. 2]. Besondere Entomologie. Zweite Abtheilung. Kaukerfe. Gymnognatha. (Zweite Hälfte; vulgo Neuroptera). Theod. Chr. Friedr. Enslin, Berlin, 757-1050.

Costa A (1855) [1855.11.03-1871.01.07] Fauna del Regno di Napoli ossia enumerazione di tutti gli animali che abitano le diverse regioni di questo regno e le acque che le bagnano e descrizione de' nuovi o poco esattamente conosciuti con figure ricavate da originali viventi e dipinte al naturale. Nevrotteri. Napoli.

Curtis J (1834) [1824-1839] British Entomology; being illustrations and descriptions of the genera of insects found in Great Britain and Ireland: containing coloured figures from nature of the most rare and beautiful species, and in many instances of the plants upon which they are found. London.

Enderlein G (1905) Conwentzia pineticola nov. gen. nov. spec. eine neue Neuroptere aus Westpreussen. Bericht des Westpreussischen Botanischen-Zoologischen Vereins 26/27(Anlagen): 10-12.

Garzón-Orduña IJ, Menchaca-Armenta I, Contreras-Ramos A, Liu X, Winterton SL (2016) The phylogeny of brown lacewings (Neuroptera: Hemerobiidae) reveals multiple reductions in wing venation. BMC Evolutionary Biology 16(192): 1-19. https://doi.org/10.1186/ s12862-016-0746-5

Hagen HA (1866) Hemerobidarum Synopsis synonymica. Stettiner Entomologische Zeitung 27: 369-462.

Handschin E (1955) Los insectos de las Islas Juan Fernandez, 15. Neuroptera. Revista Chilena de Entomología 4: 3-20.

Kimmins DE (1936) New species of Nusalala (Neuroptera, Hemerobiidae). Annals and Magazine of Natural History 17(10): 568-576. https://doi.org/10.1080/00222933608655156

Lara RIR, Perioto NW (2016) Updated checklist of Hemerobiidae (Neuroptera) from Brazil and new distributional records in the Neotropical Region. Acta Amazonica 46(4): 425-432. https://doi. org/10.1590/1809-4392201600883

Martins CC (2019) Neuropterida from South America: large diversity, largely unknown. In: Weihrauch F, Frank O, Gruppe A, Jepson JE, Kirschey L, Ohl M (Eds) Proceedings of the XIII International Symposium of Neuropterology, 17-22 June 2018, Laufen, Germany: 145-161. Osmylus Scientific Publishers, Wolnzach. https://doi. org/10.5281/zenodo.3569393

Messner B (1965) Helicoconis aptera n. spec., ein neuer Vertreter der Unterfamilie Aleuropteryginae (Planipennia, Coniopterygidae) aus Bulgarien. Deutsche Entomologische Zeitschrift, Berlin (N.F.) 12: 337-340. https://doi.org/10.1002/mmnd.4810120408

Monserrat VJ (2000) Revisión del género Nusalala (Neuroptera, Hemerobiidae). Fragmenta Entomologica 32(1): 83-162.

Monserrat VJ (2004) Nuevos datos sobre algunas especies de hemeróbidos (Insecta: Neuroptera: Hemerobiidae). Heteropterus Revista de Entomología 4: 1-26.
Navás L (1913) Névroptères. Mission du Service Géographique de 1'Armée pour la mesure l'un arc de méridien équatorial en Amérique du Sud sous le contrôle scientifique de l'Académie des Sciences 1899-1906. Tome 10 (Entomologie - Botanique), Fascicle 1 (Hyménoptères, Orthoptères, Névroptères, Araignées). Paris, 69-77.

Oswald JD (1993) Revision and cladistic analysis of the world genera of the family Hemerobiidae (Insecta: Neuroptera). Journal of the New York Entomological Society 101: 143-299.

Oswald JD (1996) [1997] A new brachypterous Nusalala species from Costa Rica, with comments on the evolution of flightlessness in brown lacewings (Neuroptera: Hemerobiidae). Systematic Entomology 21(4): 343-352. https://doi.org/10.1111/j.1365-3113.1996. tb00603.x

Oswald JD (2020) Bibliography of the Neuropterida. http://lacewing. tamu.edu/Biblio/Main [Last accessed 21.06.2020]

Oswald JD, Machado RJP (2018) Biodiversity of the Neuropterida (Insecta: Neuroptera, Megaloptera and Raphidioptera). In: Foottit RG, Adler PH (Eds) Insect Biodiversity: Science and Society (Vol. II), First Edition, John Wiley \& Sons, New York, 627-671. https://doi. org/10.1002/9781118945582.ch21

Pantaleoni RA, Letardi A (1996) A remarkable brachypterous female of Dilaridae (Dilar parthenopaeus Costa) (Neuroptera). Abstract from the Program of the XX International Congress of Entomology, Florence, August 25-31 1996.

Penny ND (1996) A remarkable new genus and species of Ithonidae from Honduras (Neuroptera). Journal of the Kansas Entomological Society 69: 81-86.

Penny ND, Sturm H (1984) A flightless brown lacewing from Colombia (Neuroptera, Hemerobiidae). Spixiana 7(1): 19-22.

Rambur P (1842) Histoire Naturelle des Insectes, Névroptères. Librairie Encyclopédique de Roret. Fain et Thunot, Paris, 534 pp.

Rausch H, Aspöck H, Aspöck U (1978) Beschreibung von Helicoconis sengonca n. sp., einer neuen Coniopterygiden-Spezies aus Anatolien, und Bemerkungen über Helicoconis aptera MESSNER, 1965 (Neuropteroidea, Planipennia). Zeitschrift der Arbeitsgemeinschaft Österreichischer Entomologen 30(1/2): 25-28.

Tauber CA, Tauber MJ, Giffin JG (2007) Flightless Hawaiian Hemerobiidae (Neuroptera): Comparative morphology and biology of a brachypterous species, its macropterous relative and intermediate forms. European Journal of Entomology 104(4): 787-800. https:// doi.org/10.14411/eje.2007.100

Tillyard RJ (1916) Studies in Australian Neuroptera. No. iv. The families Ithonidae, Hemerobiidae, Sisyridae, Berothidae, and the new family Trichomatidae; with a discussion of their characters and relationships, and descriptions of new and little-known genera and species. Proceedings of the Linnean Society of New South Wales 41 : 269-332. https://doi.org/10.5962/bhl.part.15316

Tjeder B (1960) A new subapterous coniopterygid from Denmark (Neuroptera). Entomologiske Meddelelser 29: 312-319.

Wagner GP (2007) The developmental genetics of homology. Nature Reviews Genetics 8(6): 473-479. https://doi.org/10.1038/nrg2099

Zimmerman EC (1957) Order Neuroptera. In Insects of Hawaii (Vol. 6). University of Hawaii Press, Honolulu, 19-169. 